for its investigations of the morphology of the human embryo and the comparative physiology of the reproductive system, the morphological research being centred on the Department's superb collection of human embryos. Under Prof. Ebert's leadership it is expected that workers in the Department will pay increasing attention to the study of the basic mechanisms of differentiation, growth and morphogenesis of the early embryo, using the technical advances in such fields as immunochemistry, protein physical chemistry and virology to link up our knowledge of reactions at the cell group and tissue level with the reactions of specific molecules.

\section{Hunsaker Chair of Aeronautical Engineering at the Massachusetts Institute of Technology: Prof. W. R. Hawthorne}

Prof. W. R. HAW'THoRNe, Hopkinson and Imperial Chemical Industries, Ltd., professor of applied thermodynamics in the Department of Engineering, University of Cambridge, is at present on leave of absence at the Massachusetts Institute of Technology and has been appointed for the current academic year to a new chair at the Institute, the Jerome Clarke Hunsaker chair of aeronautical engineering. Prof. Hawthorne's principal interests are in the fields of aircraft propulsion and advanced fluid mechanics, and at the Institute he will divide his lecturing between the Departments of Mechanical and Aeronautical Engineering. During his tenure he will deliver the Minta Martin Aeronautical Lecture. The Hunsaker chair was established last year in honour of Prof. J. C. Hunsaker, founder and for many years head of the Aeronautical Engineering Department at the Institute and a leading figure in American aviation. He retired in 1952 but is still closely associated with the Institute. The founding of the chair has been largely due to Major Lester D. Gardner, of New York, an alumnus of the Institute and one of the founders of the Institute of the Aeronautical Sciences; more than 360,000 dollars has been raised, and it is hoped to increase this eventually to 500,000 dollars.

\section{G. Groves Memorial Prizes and Award of the Air Ministry}

Two L. G. Groves Memorial Prizes and an Award are made annually by the Air Ministry from a fund established in 1946 by Major and Mrs. Keith Groves in memory of their son, Sergeant Louis Grimble Groves, R.A.F.V.R., a meteorological observer who lost his life on a weather flight in 1945. The recipients this year are as follows: Prize for Aircraft Safety, to Squadron-Leader J. Harvey (technical staff, Headquarters, Fighter Command) for designing an alteration to the fuel system of the Meteor night-fighter, which provides the aircraft with automatic operation of the fuel system from all tanks, in place of the original arrangement of individual tank selection by the pilot, and thereby greatly enhances its safety; Prize for Meteorology, to Dr. F. J. Scrase (principal scientific officer and leader of the Instrument Development Division of the Meteorological Office) for his research on turbulence in the upper atmosphere and theoretical investigation of the errors, due to radiation and lag, of radiosondes, studies which are closely related to practical problems of aviation and air navigation, and also for his work as president of a sub-commission of the World Meteorological Organization responsible for the new "Guide to Inter- national Meteorological Instrument Practice"; Award for Meteorological Observers, to Flight-Lieutenant $\mathrm{J}$. Formby (of Short Bros. and Harland, Ltd.), for his work since September 1952 in carrying out meteorological ascents under contract with the Air Ministry amounting to more than $\mathbf{4 5 0}$ flights in Spitfire aircraft from the R.A.F. Station, Woodvale, Lanes, and involving exceptional ability both as a pilot and as a meteorological observer.

\section{Central Advisory Water Committee}

Mentings of the Central Advisory Water Committee, appointed by the Minister of Housing and Local Government, are being resumed, and the first will be held on October 31. The Minister, Mr. Duncan Sandys, is chairman of the Committee, and the vicechairman is the Parliamentary Secretary, Mr. William Deedes. The Committee was first set up in 1946, under the Water Act, 1945, and has issued a series of reports on river pollution, water softening, gathering grounds and land drainage. Its sittings were suspended in 1952, and its revival has necessitated the appointment of new members, the terms of appointment of the previous members having lapsed. The members are : Sir David Brunt, secretary and vice-president, Royal Society; Mr. John Cockram, chairman, Water Companies Association ; Lieut.-Col. J. Godman, chairman, Severn River Board; Coun. A. Gorman, chairman, Metropolitan Water Board; Sir Arthur Heneage, president, River Board Association and chairman of the Lincolnshire Branch, Country Landowners Association; Dr. N. R. Hood, director, British Paper and Board Industry Research Association; Mr. H. F. Hopthrow, assistant secretary, Imperial Chemical Industries, Ltd. ; Sir Reginald Kerr, chairman and general manager, British Transport Waterways; Prof. W. B. R. King, sometime professor of geology, University of Cambridge; Mr. W. C. Knill, vice-president, Association of Waterworks Officers; Mr. C. E. Lucette, manager and secretary, Manchester Ship Canal Co.; Mr. A. G. McLellan, engineer and general manager, Sunderland and South Shields Water Co.; Canon W. Marsden, chairman, Public Health Committee, Rural District Councils Association ; Mr. G. S. Mason, chairman, Pollution Prevention Committee, River Boards Association; Mr. W. A. Muddell, chairman, Trent River Board; Prof. J. Proudman, sometime professor of oceanography, University of Liverpool ; Lord De Ramsay, president, Association of Drainage Authorities ; Mr. J. H. T. Stilgoe, engineer, Liverpool Water Undertaking; Mr. A. Titherley, director, Mid-Kent Water Co.; Ald. J. R. Wardell, past president, British Waterworks Association; Mrs. Charles Williams, chairman, Public Health Committee, Cornwall County Council; Mr. Harold Woolley, vice-president, National Farmers Union; Ald. R. C. Yates, president, British Waterworks Association; Secretary, Miss M. E. Petzsche, Ministry of Housing and Local Government; Assistant Secretary, Mr. G. D. Vaughan, Ministry of Housing and Local Government.

\section{Photobiology Group : Inaugural Meeting}

THE inaugural meeting of the Photobiology Group was held in Bedford College, London, on October 3, and about seventy members participated. A series of review papers was presented on different aspects of the biological action of light. Dr. E. J. Bowen (Oxford) opened the meeting with an account of work on triplet states in excited molecules, in which he 